ISSN 2616-7328 (Online); ISSN 2409-904X (Print)

Kitaêznavčì doslìdžennâ, 2020, No. 1, pp. 47-68

doi: https://doi.org/10.15407/chinesest2020.01.047

UDC 94

\title{
THE 1980S AND 1990S CHINESE DEBATES ON SOCIALISM: THE CASE OF GORBACHEV'S GLASNOST
}

Jie $\mathrm{Li}$

$\mathrm{PhD}$ in History at the University of Edinburgh in 2017

3 Floor, 21 Ferry Street, Yau Ma Tei, Jordan, Kowloon, Hong Kong

jielican2009@hotmail.com

Mikhail Gorbachev's glasnost (openness) was a popular topic in 1980s China. Existing scholarship remarks that Chinese Soviet-watchers admired Gorbachev's programme as a model for China's democratisation in the 1980s. However, after 1991, because of their impact on China's pro-democracy movements as perceived by the Chinese government, the same Chinese scholars consistently criticised Gorbachev and his liberalisation policies for being the fundamental catalysts in bringing down the USSR.

This paper suggests that the attractiveness of Gorbachev's glasnost policy to 1980s Chinese Sovietologists was not because it symbolised Western-style democracy; instead, they embraced glasnost as a type of government-led democracy. The impact of Gorbachev's policies after the mid-1990s can also be seen in Chinese scholars' use of them to support the reformist General Secretary Zhao Ziyang in his power struggle against the Party conservatives leading up to the Tiananmen Incident.

This paper further posits that Chinese scholars' scorn for Gorbachev after Tiananmen was not primarily owing to his role in promoting democratisation; rather, it was because of Gorbachev's soft line approach towards dissent when communism in Europe was on the verge of collapse. By drawing attention to Gorbachev's soft line approach, Chinese critics justified China's use of the Tiananmen crackdown and the brutal measures adopted by Deng Xiaoping to preserve the socialist rule and social stability.

Keywords: Mikhail Gorbachev, Deng Xiaoping, Zhao Ziyang, Chinese Sovietology, Tiananmen, contemporary China, post-communism

\section{The University of Edinburgh}

\section{Introduction}

Several previous scholars have noted the enormous impact that the last leader of the Soviet Union, Mikhail Gorbachev, and his political liberalisation policy known as glasnost (openness) had on 1980s China [Sun 1995, 242-246; Guan 2010, 511513; Shambaugh 2008, 55-57]. It has been reported that Gorbachev's programme inspired the former Party General Secretary Zhao Ziyang's political reform proposal on the eve of the Tiananmen Incident in 1989 [Wu 1997, 306]. He was held in enormously high esteem among Chinese intellectuals in the 1980s [Brown 2007, 107]. His enthusiasm for freedom and the reform of socialism were instrumental

C 2020 Jie Li; Published by the A. Yu. Krymskyi Institute of Oriental Studies, NAS of Ukraine and the Ukrainian Association of Sinologists on behalf of The Chinese Studies. This is an Open Access article distributed under the terms of the Creative Commons Attribution License (https://creativecommons.org/licenses/by-nc-nd/4.0/). 
in stirring up the student protests in Tiananmen Square. Demonstrators used his example to pressure the Chinese leader Deng Xiaoping into abandoning the authoritarian rule of the Chinese government [Lukin 1991, 123]. Moreover, the existing literature points out that Chinese Sovietologists admired Gorbachev's political reform as a model for China's democratisation in the 1980s. However, after 1991, because of their impact on China's pro-democracy movements as perceived by the Chinese government, the same Chinese scholars consistently criticised Gorbachev and his liberalisation policies for being the fundamental catalysts in bringing down the Union of Soviet Socialist Republics (USSR) [Marsh 2005, 105-106; Shambaugh 2008, 57].

Having examined a range of academic and official articles published in China from the $1980 \mathrm{~s}$ to the $1990 \mathrm{~s}$, I would first argue that the attractiveness of Gorbachev's glasnost policy to 1980s Chinese scholars was not because it symbolised Western-style democracy; instead, they embraced glasnost as a type of "democracy under socialism", and saw it as being equivalent to the "neo-authoritarianism" of Zhao Ziyang that championed pluralism under a strong government. Moreover, the impact of Gorbachev's policies after the mid-1980s can also be seen in Chinese scholars' use of them to support the reformist leader Zhao in his power struggle against the conservatives within the Chinese Communist Party (CCP) leading up to the Tiananmen Incident in 1989. This paper further posits that Chinese scholars' scorn for Gorbachev after Tiananmen was not primarily owing to his role in promoting democratisation; rather, it was because of Gorbachev's soft line approach towards dissent when communism in Europe was on the verge of collapse. By drawing attention to Gorbachev's soft line approach, Chinese critics justified China's use of the Tiananmen crackdown and the brutal measures adopted by Deng Xiaoping to preserve the socialist rule and social stability. Having said this, the wave of Chinese criticisms was a short-term phenomenon. It gradually receded after the mid-1990s as a result of the marked improvement in Sino-Russian relations after the collapse of the Soviet Union, and most importantly, as a result of China's own reflections on the lessons already learned from the Sino-Soviet ideological disputes that had taken place under Mao Zedong.

With respect to primary sources, it should be mentioned here that this research is based wholly on the "national core journals" (Guojiaji hexin qikan) published in the People's Republic of China (PRC), and mainly on the following four categories of journals:

The first are those journals focusing on research in the humanities and social sciences in general (Shehui kexue yanjiu, Shijie jingjiyu zhengzhi). Second are those journals dealing with problems of socialism or communism in the world (Dangdai shijie shehui zhuyi wenti, Shehui zhuyi yanjiu). The third group forms the core of this study; they concentrate on questions and issues relating to the former Soviet Union (later the Russian Federation and other Commonwealth Independent States after 1991) (Sulian dongou wenti, Eluosi yanjiu). Lastly, the research scope also included relevant articles in various university journals (Zhongguo shehui kexueyuan yanjiu shengyuan xuebao, Zhonggong zhongyang dangxiao xuebao).

Moreover, the paper examines the thinking of Chinese Sovietologists against the backdrop of political developments in the PRC from the mid-1980s to the 1990s. Therefore, in order for this research to be successfully located in the rich fabric of intellectual activities and the changing environment of contemporary China, the investigator also consulted China's Party newspapers and journals, such as the 
Renmin ribao (People's Daily), Guangming ribao (Guangming Daily) and Beijing Review (English edition), and the writings and speeches of PRC officials, such as those of Deng Xiaoping and other contemporary Chinese leaders.

The use of the term "Sovietologists" (or Soviet-watchers) - those who study and research the state of the USSR - in this paper is based on Christopher Xenakis' definition. Xenakis defines Sovietologists broadly, to include "political scientists, economists, sociologists, historians, diplomats and policy makers, working in academia, government, private think tanks, and the media." He uses the terms "Sovietologists", "Soviet experts", "foreign policy analysts", "Cold War theorists", and "political scientists" interchangeably, citing the examples of George Kennan, Zbigniew Brzezinski, Richard Pipes and Strobe Talbott [Xenakis 2002, 4].

In terms of this elastic definition of the field and the diversity of scholars' backgrounds, the situation in China is generally similar to the situation in the US described by Xenakis. For example, as we will see, although some Chinese scholars specialise in either Soviet or world communism, most of those mentioned and quoted in this paper are generalists rather than specialists in Soviet studies. Their articles often express more political zeal than scholarly expertise or analytical insight. Generally speaking, the descriptions of Xenakis of US Sovietologists could also be applied to the Chinese situation. Chinese Soviet-watchers are a diverse group, rather than representatives of a single school of thought or central theory. Their publications never imply a complete homogeneity of views. However, although their academic training is in different disciplines and by no means confined to Soviet studies, their research and publications are relevant to Sovietology in one way or another.

\section{Chinese Perceptions of Gorbachev across the 1990 Divide}

One thing that should be noted is that Chinese perceptions of Gorbachev from the mid-1980s onwards were quite evolutionary. Views changed not only in response to the ups-and-downs of Sino-Soviet (and later Sino-Russian) relations and China's domestic political climate, but also in response to the political developments in Moscow. The existing secondary literature on Chinese Sovietology indicates that Chinese scholars began making positive comments about Gorbachev immediately after he assumed power in 1985 [Bernstein 2010, 2; Rozman 1987, 130-135; 2010, 455], but that soon after the Tiananmen Incident in 1989 they had become completely hostile to the last Soviet leader and their criticisms did not stop even after the collapse of the USSR in 1991 [Rozman 2010, 460; Shambaugh 2008, 57; Marsh 2005, 105-106; Wilson 2007, 271].

My reading shows, however, that most of the Chinese academic commentators on the USSR did not have positive views of Gorbachev either in or after 1985. Many scholars remained suspicious of Gorbachev and felt uncertain about his future manoeuvers and agendas. The main reason for China's lukewarm reaction to the Soviet leader during the early days of his administration was the tense Sino-Soviet relations at that time, notably the unresolved question of the three obstacles (the Soviet invasion of Afghanistan, its large troop deployment along the border with China, and Moscow's support of the Vietnamese military intervention in Cambodia) plaguing the two countries. In 1985, the CCP regime expressed its concern regarding Gorbachev's reluctance to resolve these unsettled problems after he assumed power [Beijing Review $6^{\text {th }}$ May 1985, 13]. In 1986, the Chinese Premier, Hu Yaobang, complained to journalists that, "Sino-Soviet relations have not made any 
headway since Gorbachev assumed power" [Renmin ribao $20^{\text {th }}$ June 1986,1$]$. At the same time, some Chinese Soviet-watchers also expressed their resentment of Moscow's insincere approach towards removing the three obstacles. They pointed out that this behaviour ran counter to the principle of New Thinking [Ma 1986, 52; Xing 1986, 36; Zhu 1987, 29]. Only around one year after Gorbachev took the helm did Chinese scholars start to review his policies positively, when the problem of the three obstacles had started to be resolved and bilateral relations were gradually improving.

My findings also demonstrate that in and after the 1989 Tiananmen uprising, no major criticisms of Gorbachev appeared in Chinese academic writings. Instead, Chinese scholars still seemed to have admired and poured out their positive evaluations of his programmes during this anti-liberal period in contemporary China. There are several reasons why Gorbachev was by no means of a subject of ridicule in the eyes of Chinese scholars in the wake of the Tiananmen demonstrations. First, the Chinese leadership had by then taken stock of the Sino-Soviet frictions under Mao Zedong, and did not want to be at odds with a large and powerful country that had the longest borderline with the PRC. When the Sino-Soviet summit meeting took place in May 1989, both sides placed great emphasis on the principle of mutual non-interference in each other's internal affairs and normalised the relations between the two countries. Having learned from the lessons of history, they were committed to not letting ideological disagreements disrupt cordial bilateral relations [Guangming ribao $19^{\text {th }}$ May 1989, 1]. All this is reflected in the main import of Deng's summit conversation with Gorbachev - putting the past behind, opening up a new era, doing more practical things and indulging in less empty talk [Deng 1994b, 287]. Harmony and rapport between the two nations would be the primary considerations, despite the fact that some officials and scholars might feel suspicious of Gorbachev's reform programmes.

Second, it was Gorbachev who mended the Sino-Soviet fences after the protracted period of mutual distrust, repairing the relationship almost on Chinese terms. Gorbachev may not have agreed in his heart with China's strategy of violence in handling the Tiananmen Incident [Gorbachev and Ikeda 2005, 2], but even when he was pushed by Western reporters during his visit to Beijing in 1989, the Soviet leader refused to comment on the student movements [Guangming ribao $18^{\text {th }}$ May 1989, 3], and he did not encourage the Soviet media to criticise the Chinese government after he returned to Moscow [Marsh 2005, 136-137]. It may therefore have gone against the grain for the Chinese state to start criticising someone who had made a significant contribution to the Sino-Soviet rapprochement and who had adopted a neutral position when China was experiencing domestic problems.

Last, in the wake of the Tiananmen Incident, China did not consider that Gorbachev and his liberalisation policies posed an immediate threat to its socialist system. In fact, the West was perceived as a danger to the survival of the regime that loomed far larger than the USSR [Xu 1989, 5-6; Guangming ribao $4^{\text {th }}$ September 1989, 3], and the CCP saw the Soviet state as a much-needed partner with which China could confront Western power politics [Beijing Review $3^{\text {rd }}-9^{\text {th }}$ September 1990, 11]. After the Tiananmen Incident, many Chinese Party leaders were keen to maintain relations with Moscow, expressing their hopes that the USSR would still uphold the ideals of socialism [Renmin ribao $27^{\text {th }}$ April 1990, 4; Renmin 
ribao $31^{\text {st }}$ May 1990, 3]. This is because international sanctions were already being imposed on China and the West was exerting pressure on the PRC to give up its oppressive rule after Tiananmen. In addition, by the 1990s the US had achieved "superhegemonist" status, forcing other countries to follow the Western model of development, and China suspected the Americans of having the intention of relegating China and various other nations to subordinate roles on the world stage [Kagan 2008, 33].

Most importantly, the investigator found that China's strong criticisms of Gorbachev did not appear until early 1990, and not immediately after Tiananmen as existing secondary scholarship claims. After Gorbachev was elected President of the USSR, and after he initiated the process of terminating the power monopoly of the Communist Party of the Soviet Union (CPSU) on March 15 1990, both the CCP and Chinese scholars became aware of the possible negative ramifications of such a move on the PRC, which is committed to the communist one-party rule, and in a speech made immediately afterwards on March 18, CCP General Secretary Jiang Zemin gave the following warning:

Our Party is the ruling party, which means that the Party has an absolute leadership over the state organs. If we renounce this leadership, then the Party will no longer enjoy ruling party status. Therefore, all the state organs, including the People's Congress, the government, the Supreme People's Court and the Supreme People's Procuratorate, should be under the leadership of the Party. Any thoughts on or practices involving weakening or undermining the authority of the Party are wrong [Jiang 2006, 112].

In reaction to the alarming announcement after the $28^{\text {th }}$ CPSU Congress in July 1990 that the monopoly of communist power in the Soviet state had been officially abolished, in September of that year Jiang made the following more severe criticism:

After Soviet-American detente and the turmoil in Eastern Europe, there are indeed many communists in the world who have doubts about the future of socialism, and are even losing faith in it. But the reality has proved that this kind of thinking is terribly naïve [Jiang 2006, 134].

One week after the August 1991 coup in Moscow, Guangming ribao published an article implicitly attacking Gorbachev and his liberal programmes:

Some thoughts against Marxism and Leninism are rampant in today's international society. They have crept into the communist parties of some countries and become the guiding principles of those parties. Those thoughts are the fundamental origin of the crisis of some socialist states. The opportunists inside the international communist movement flaunt the banners of 'diversity', 'universal human value' and 'democracy is the highest principle of socialism' to confuse the masses. They are in fact writing off the class struggle, socialism and proletarian dictatorship. They stand for using the Western model to replace the communist leadership and its theoretical premise of Marxism [Guangming ribao $26^{\text {th }} \mathrm{Au}-$ gust 1991, 3].

This practice of Gorbachev's overtuning the dictatorship of the communist party was absolutely unacceptable to the CCP. Chinese scholars began to sense its potential implications for China, which were far more ominous than the effect of New Thinking and glasnost that had allegedly fuelled the student unrest in 1989 [Lukin 1991, 123]. At that time Beijing was confronting the perceived threat 
of "peaceful evolution" from the West [Shambaugh 2008, 55], and the Chinese leadership similarly feared that the abandoning of socialism by the Soviet Union would reignite pro-democracy sentiments at home and challenge its legitimacy. After this, the last Soviet leader was doomed to become the focal point of attack by the Chinese.

Some authors of the secondary literature argue that after 1991 most Chinese scholars focused on criticising Gorbachev and his liberalisation policies as the fundamental catalysts in triggering the collapse of the Soviet state [Guan 2010, 509514; Marsh 2005, 111; Shambaugh 2008, 81]. In reality, Chinese Sovietology writings never excoriated Gorbachev in the 1990s, and the torrent of attacks had gradually subsided by the middle of the decade. One major reason for this may be the improvement in Sino-Russian relations after the tragic collapse of the USSR. Once in power, Russian President Boris Yeltsin told Chinese Foreign Minister Qian Qichen that China and Russia should not put the clock back to when both sides were at each other's throats, and the ideological difference should not become a barrier to normal bilateral relations [Renmin ribao $26^{\text {th }}$ November 1992, 1]. With this overture from Russia, China decided to solidify the relations. During Jiang Zemin's visit to Moscow in September 1994, both sides confirmed their future new type of cooperation - "constructive partnership" (jianshexing huoban guanxi) [Renmin ribao $4^{\text {th }}$ September 1994,1$]$.

Moreover, after the collapse, China wanted its bordering Commonwealth Independent States (CIS) to remain stable, otherwise they would create grave problems for the PRC. After the Cold War the CCP leadership not only needed good relations with Russia in diplomatic terms, but also expected to retain Russia and other CIS as a counterbalance in resisting the Western notion of peaceful evolution, which they saw as a threat. Therefore, it was a rational decision for Chinese scholars after 1991 not to indulge in a negative critique of the defunct Soviet socialism founded by the Russians in 1917, since this would arouse suspicions on the Russian side and ultimately harm the relationship. In a 1999 speech delivered to a conference commemorating the 50-year anniversary of Sino-Russian relations, at which the Vice-Director of the International Liaison Department of the CCP, Cai $\mathrm{Wu}$, and Russian Ambassador Igor Rogachev were present, Li Jingjie, Director of the Chinese Academy of Social Sciences (CASS), cited the main import of Deng Xiaoping's conversation with Gorbachev in 1989 - "putting the past behind and embracing the future" - and made it clear to Chinese scholars that they should "no longer cling to the old scores of history" when they were conducting research into Sino-Russian relations in the future [Li 1999, 4]. In another article published at the same time, Pan Zhengxiang, a scholar at the Chinese University of Science and Technology, retraced the sorry history of Sino-Soviet relations and asked Chinese scholars to take the lessons of the past into account in their future research. He instructed them to "uphold the notion of seeking common ground while preserving differences", and warned them "not to engage in open polemics and in criticising Party or state leaders on the other side by name" in order to "prevent the repeating of historical tragedy in the $21^{\text {st }}$ century" [Pan 1999, 46].

Last, Gorbachev and his liberal programmes were by no means the only, or even the most significant, factor in the USSR's dissolution, as claimed by Chinese analysts after 1991. Since the mid-1990s, some Chinese scholars have traced the roots of the tragedy back to the administrations of Leonid Brezhnev and Joseph Stalin, 
arguing that the conservative forces and the rigid communist system were the decisive factors in bringing it about - rather than the figure of Gorbachev alone [Huang 1993, 39-46; Zheng 1995, 7-12; Zuo 1996, 57-63].

\section{The Popularity of Gorbachev in 1980s China}

As stated above, Gorbachev's glasnost was a popular topic in 1980s China. Zhao Ziyang once said that Soviet glasnost had more impact than "Western values, concepts and political systems" in encouraging "China's intellectuals, youth and young workers to demand more democracy" in the 1980s [Bao 2009, 261]. When Zhao was in power in the mid-1980s, with Deng Xiaoping's approval, he organised and supervised the first political reform group since the founding of the PRC to design a proposal for the institutional restructuring of the CCP [Renmin ribao $28^{\text {th }}$ February 1988,1$]$. Wu Guoguang, former advisor to Zhao and the chief editor of the Renmin ribao in the late 1980 s, has revealed that during this period of formulating political reform, Zhao's aim was to learn from Gorbachev and implement economic and political reforms in China concurrently. The General Secretary always asked the staff to collect the minutes of the CPSU Congress, at which Gorbachev had delivered his speeches, to give him inspiration for China's political reform [Wu 1997, 306]. In addition, Zhao occasionally invited the PRC ambassador to Moscow and some well known Chinese Soviet specialists to give him seminar talks on Soviet glasnost [Wu 1997, 181]. After he was removed from the leadership owing to his unwillingness to endorse the Tiananmen crackdown ordered by Deng Xiaoping, Zhao admitted that his thinking on political reform had been changed in 1985/1986, "aroused somewhat by events in the broader international environment and problems that had emerged in the Eastern Bloc" [Bao 2009, 256-257].

After the mid-1980s, not only Zhao Ziyang, but also other CCP leaders, such as Tian Jiyun and Bo Yibo, expressed their admiration for Gorbachev's programme and their willingness to learn from the Soviet experience [Renmin ribao $11^{\text {th }}$ January 1988,4 ; Renmin ribao $13^{\text {th }}$ July 1988,1$]$. The official recognition obviously stimulated the intellectual fever. In a speech given to the National Social Sciences Congress in April 1988, CASS President Hu Sheng complained that China had not done much research on Soviet politics before, owing to the Sino-Soviet conflicts, which meant that Chinese scholars had an insufficient knowledge of recent developments, such as glasnost, in the Soviet Union. Hu urged the Chinese people to conduct research into "Soviet political and economic structural reforms immediately", as "those reforms are analogous to what China has undertaken", stating that such comparative studies were "necessary and beneficial" [Hu 1988, 6-7]. At the same time, some Chinese scholars expressed their utmost appreciation for and excitement regarding Gorbachev and his political reform. Upon hearing the Soviet announcement of the termination of the concentration of power in the hands of the Communist Party and the life-long tenure of the General Secretary at the 27th CPSU Congress, Gao Fang, a professor of the history of communism at Renmin University, predicted that Gorbachev might become "a proletarian George Washington" and bring "a blessed message to socialism" [Gao 1988, 8]. Zhao Yuliang, a professor of economics at Beijing Jiaotong University, foresaw that Gorbachev's reform would be "another epoch-making revolution comparable to the one under Peter the Great in Russian history" [Zhao 1988, 27].

The reasons for China's positive response to the Soviet glasnost and the positive impression of Gorbachev himself after 1986 were manifold. The most important of 
these was the extraordinary openness and budding democracy of the Chinese political environment after the mid-1980s. At a national symposium in 1986, VicePremier Wan Li had already called for the introduction of a "more democratic and scientific policy decision-making process" in the CCP [Beijing Review $11^{\text {th }}$ August 1986, 5]. In 1988, one author publicly demanded the end of censorship in China [Renmin ribao $2^{\text {nd }}$ February 1988, 8]. In the realm of academia, in 1986 the Editorial Board of Shehui kexue yanjiu (Social Science Research), funded by the Sichuan Provincial Academy of Social Sciences, published an article in which, after a re-examination of the disastrous decade of the Cultural Revolution, it was suggested that China learn from the West in "instituting political democratization and allowing intellectuals to be critical of those in power" [The Editorial Board 1986, 129]. At the CASS, a new policy issued in early 1989 encouraged scholars to "apply research methodologies that are not involved in Marxist theory, as long as they abide by the Chinese Constitution" [Renmin ribao 17 th January 1989, 3].

Second, since the mid-1980s China had placed political reform high on the agenda. In 1986, Deng Xiaoping acknowledged that, "without political reform, economic reform cannot succeed" [Deng 1994b, 167]. Back then, even the Party conservatives, such as Peng Zhen and Bo Yibo, also voiced their support for initiating political reform in China [Renmin ribao $6^{\text {th }}$ August 1986, 1; Renmin ribao $13^{\text {th }}$ July 1988,1$]$. In conjunction with the official mandate, several articles suddenly appeared in various journals. The authors proposed that China should closely scrutinise the experiences of political reform in Eastern Europe and the Soviet Union, and argued strongly that economic modernisation could not be realised without socialist democracy [Cai 1986, 23-24; Ling 1986, 12-13; Wu 1988, 26]. Seen from the perspective of Chinese scholars' profound esteem for glasnost, those Soviet observers might have either been genuinely impressed by Gorbachev's programme, or have wanted to speed up China's own glasnost and seek to highlight the achievements of Soviet political reform in order to give the Chinese regime the extra push that was needed for the adoption of similar measures.

\section{Chinese Understanding of Gorbachev's Glasnost}

With regard to the understanding of Chinese scholars in the 1980s of Gorbachev's glasnost and political reform, many Chinese scholarly writings did not in fact equate Gorbachev's concept and programme with political democracy in the Western sense. After 1986, many articles attempted to demonstrate that Gorbachev's reform was a return to Lenin's orthodox socialism. Some writers argued that the concept of glasnost originated from Lenin [Cui 1988, 44; Li 1988, 96]. Others appreciated Gorbachev's efforts in either re-establishing the people's right to participate in state affairs [Wu 1987, 15; Gu 1988, 28], or in reinstating democratic and humanistic socialism [Shi 1987, 3; Zheng 1988, 26]. They argued that both had been founded by Lenin, but later sabotaged by Stalin, and had not been fully recovered by the Soviet leaders after Stalin. It might be correct, according to the opening speech of the $27^{\text {th }}$ CPSU Congress in February 1986, to say that Gorbachev's reform was a return to true Leninism [Gorbachev 1987a, 10]; however, Chinese scholars had a tactical consideration in placing Gorbachev and Lenin in the same category. Since Gorbachev's programme of glasnost had spread to China, Chinese intellectuals were keen to learn from and portray it as a lesson for China, in the hope that Gorbachev's thinking might become a stimulus further political change in the PRC after the initial economic reform that was begun in 1978. It 
should be noted that a short-lived campaign against bourgeois liberalisation had emerged in the first half of 1987, after the 1986 student demonstrations and the stepping down of General Secretary Hu Yaobang, who was accused of being sympathetic to bourgeois thinking [Renmin ribao $17^{\text {th }}$ January 1987, 1]. Although the event was not large in scale and was nothing like the type of political persecutions that had taken place under Mao, however, Deng Xiaoping had made it clear in late 1986 that slogans against socialism and soft approaches towards bourgeois liberalisation would not be tolerated [Deng 1994b, 194]. It is therefore understandable that Chinese scholars chose to use the less risky theme of Lenin to channel their arguments during this sensitive period, making their interpretations less vulnerable to attack. Quoting Lenin to boost Gorbachev's positive image might encounter less political trouble and was more acceptable to the Party old guard, who were not very familiar with Gorbachev's ideas.

Having said this, Chinese scholars' cloaking of Gorbachev in the mantle of Leninism suggests that their understanding of his ideas was still orthodox in nature. As mentioned earlier, the former CCP General Secretary Zhao Ziyang was a lover of glasnost. He was favoured and supported by many Chinese intellectuals in the 1980s as the patron of political reform [Goldman 1994, 238-239]. Although Zhao's ideas looked more liberal than those of the Party old guard on the surface, however, in the eyes of Richard Baum, Zhao's thoughts on political reform still "stressed the need for strong, centralized technocratic leadership", and he was not an advocate of "Western-style liberalism, but of Chinese-style 'neo-authoritarianism"' [Baum $2008,113]$. Indeed, after having been purged in the wake of Tiananmen, Zhao revealed that he would never have countenanced a multi-party system but had advocated a reformed one-party dictatorship. He said that, "neo-authoritarianism is good for a developing country" [Zong 2007, 153-154]. The concept of "neo-authoritarianism" did not escape the attention of Chinese scholars in the 1980s. A 1989 article in Jingjixue zhoubao (Economics Weekly) stated that, "China needs a new kind of Gorbachev-like strongman" [Jingjixue zhoubao 12 ${ }^{\text {th }}$ March 1989, 22]. Zhao Liqing, an associate researcher at the Central Party School, openly remarked that, "present-day China needs democratic authoritarianism". In his opinion, for the sake of economic modernisation, "circumscription of personal freedom is essential", and "a powerful government with sufficient authority" would be the best type of government to ensure the social and political stability necessary for reform. According to the author, China should consult Gorbachev's political reform model [Zhao 1989, 36-38]. It is interesting to note that some 1980s Chinese scholars tended to regard Gorbachev's glasnost as a kind of government-led protection of citizens' rights and supervision of bureaucratic conduct. They expressed the hope that such guided democracy, whereby the people would gradually be given more say, would be introduced, while popular participation would be within limits fixed by the Party. According to their definition, this was "democracy under socialism", which, in their understanding, was equivalent to Zhao's concept of neo-authoritarianism that champions pluralism, diversity and efficiency under a strong government [Xiao 1988, 8; Zhao 1988, 14; Zhang 1989, 68].

Similarly, many Western scholars make it clear that Gorbachev's glasnost is not the same as Western democracy [Sallnow 1989, 42; Walker 1993, 97; Gooding 2001, 216]. His goal was either "a democratized one-party system" [Lewin 1991, 151] or "a more enlightened dictatorship" [Laqueur 1989, 43]. With regard to the Chinese understanding of glasnost, we need to compare the Chinese concept of 
gongkaixing (publicity) and the English idea of openness. The meaning of gongkaixing is a little different from that of openness. Gongkaixing conveys the impression that political transparency will be circumscribed by the top echelons of government to a certain extent. It is an authorised openness, not a complete openness; in other words, gongkaixing is openness licensed by the central government, rather than a fundamental political right of the citizens of a country. This difference is equivalent to the difference between rule by law and the rule of law. Lowell Dittmer profoundly captures the subtle difference between the Chinese and Western concepts:

The concept of "publicity" (gongkai) in contemporary China is derived from the age-old concept of the "public" (gong). In the Confucian classics a prominent polarity exists between the terms of "self" ( $z i)$ and "public" (gong), which is linked to an opposition between selfishness (zisi) and selflessness (wusi). The juxtaposition corresponds to the Western "public-private" distinction, though it is more invidious. Selflessness is lauded for having the interests of all the people in mind, as selfishness is condemned for a cognitive or even a moral failure to perceive the self in terms of a more comprehensive social organism to which the person's fate is inextricably connected. The Western concept of the "private" is less pejoratively defined than the Chinese, with a strong strain going back at least to Adam Smith construing the private sector as making an almost necessarily positive contribution to public welfare. Private interests per se are sanctioned by the free market model in economic thoughts, by social contract theory in politics, and by the adversary tradition in jurisprudence. The public is, to be sure, also positively evaluated in the West (e.g., "public interest", "public weal"), but even though it is favourably evaluated it has subtly different connotations from the Chinese concept [Dittmer 1994, 110-111].

Seen from these perspectives, glasnost seems to be akin to Chinese traditional thinking on political philosophy and statecraft. Chinese scholars' interpretation of glasnost appeared to converge with the substance of Zhao Ziyang's neo-authoritarianism.

\section{The Use of Gorbachev}

While Soviet political reform had been making headway since 1985, Zhao Ziyang's political reform had remained a work-in-progress since the mid-1980s, and was stillborn on the eve of the Tiananmen Incident. Zhao's reform proposals included the separation of the Party and the state, the introduction of the rule of law, and permission given to other parties to compete with the CCP in rank-and-file elections [Wu 1997, 94-107]. The CCP General Secretary once revealed that the slow progress of his political reform and the difficulty of putting it into practice were mainly owing to Deng Xiaoping's orthodox thinking and his interference, that had prevented any bold experimentation [Zong 2007, 33]. After the $13^{\text {th }}$ Party Congress in 1987, Zhao's plans for political reform were warmly welcomed by Chinese scholars [Renmin ribao $5^{\text {th }}$ March 1988, 5; Gao 1988, 10]. However, after seeing that Zhao had not transformed many of his promises into practice, from 1988 onwards the attitude of Chinese scholars became more demanding. Xiao Gu and Yang Xinyu (both were professors of Russian language at Fudan University) made strong demands that the Chinese government learn from Gorbachev and implement political and economic reforms simultaneously [Xiao 1988, 10; Yang 1988, 41]. After criticising the absence of democracy from politics since Mao, Xu Hongwu, a professor 
of Marxism-Leninism at Beijing Normal University, requested that China take notice of Gorbachev, and argued that "apart from glasnost, there is no way for China to introduce democratic politics" [Xu 1988, 23]. Zhou Yuansheng, a PhD law student at Renmin University, remarked that it was essential for the PRC to establish "glasnost with Chinese characteristics" [Zhou 1988, 26]. The reason why Chinese scholars zealously supported Zhao's proposal and consistently pressed for further political reform actions might have been the intensification of the power struggle between Zhao and the conservative forces in the CCP leading up to the Tiananmen Incident. First, if one compares Zhao's report to the $13^{\text {th }}$ Party Congress and Deng's conservative approach to political reform, one finds they are similar in substance [Zhao 1987, 3-77; Deng 1994a, 319-341]. However, Zhao's speech to the Congress was largely for public consumption. The report needed Deng's prior approval before it was delivered, and thus it may not reflect Zhao's real intentions in political reform. In his publications, Wu Guoguang reveals that Zhao's agenda was more radical than the 13th Party Congress speech suggested [Wu 2008, 38], and the CCP General Secretary even said that China's future political reform should go one step further than Gorbachev's glasnost [Wu 1997, 314]. Zhao also recalled that the political reform report presented at the Congress would have been more open and liberal if Deng had not interfered so much during the writing process [Bao 2009, 208]. Moreover, unlike Zhao and his followers, some key CCP leaders did not favour the direct borrowing of Gorbachev's programme for China even before Tiananmen. Both Foreign Minister Qian Qichen and Premier Li Peng were cautious about any radical approach towards reform, claiming that Gorbachev's political reform model was unsuitable for China, on the grounds that both countries had very different social, political, economic and geographical conditions [Beijing Review $10^{\text {th }}-16^{\text {th }}$ April 1989,14 ; Beijing Review $17^{\text {th }}-23^{\text {rd }}$ April 1989, 12]. As the power struggle in the higher echelons of the Party escalated in the period before the student demonstrations, some Chinese scholars seemed to position themselves on the side of the reformers in an effort to weed out the conservatives. David Shambaugh reveals that the time when Chinese scholars were commending Gorbachev's glasnost "was precisely the time that Zhao Ziyang and his advisers were pushing political reform", and that it also coincided with "a fierce intraparty debate within the CCP, and considerable swelling opposition to Zhao and his reforms" [Shambaugh 2008, 56]. Prior to the Tiananmen Incident, CASS researcher Wang Yizhou stated unequivocally that China should learn from Gorbachev's political reform how to "overcome the inertia, conservatism and dogmatism among the bureaucracy", and "get rid of the politics of septuagenarians" [Wang 1989, 24]. Shen Yiming (a researcher at Qinghua University) argued that through Gorbachev's glasnost socialist pluralism had spread all over the world [Shen 1989, 21]. He boldly commented:

We should not exclude the possibility that there could be several Marxist parties existing side by side in a socialist state. Although the struggle to achieve political pluralism is extremely fierce, however, political pluralism will be an irresistible trend nonetheless, as long as the ruling party starts to admit its weakness and give way to a more correct reform line; therefore, a healthy pluralist political mechanism will finally come [Shen 1989, 22].

\section{The Misuse of Gorbachev}

Some of the secondary literature suggests that after 1991 Chinese scholars tended to blame Gorbachev's programmes, such as glasnost and liberalisation, for being 
the fundamental causes of the downfall of the USSR because those scholars felt extremely nervous about the negative implications of these policies for China [Guan 2010, 509-514; Rozman 2010, 464; Wilson 2007, 272]. First, a perusal of the primary documents in which Chinese scholars expressed their criticisms after March 1990, when Gorbachev was launching the process of ending the CPSU monopoly, reveals that most scholars did not oppose Gorbachev's political reform of socialism. Some disputed Gorbachev's notion that political reform should precede economic reform, and remarked that the former should serve the needs of the latter [Xu 1991, 14; Zhang 1992, 17; Tong 1993, 12]. Others criticised Gorbachev's programme for being too Western-oriented, and in particular criticised his termination of the CPSU power monopoly as an incorrect method of political reform [Yan 1990, 5; Wei 1991, 17; Jiang 1993, 53].

Second, this paper further posits that Chinese scholars' scorn for Gorbachev after 1990 was not primarily owing to his role in promoting democratisation and changing the nature of socialism; rather, it was because of Gorbachev's soft line approach towards dissent when communism in Europe was on the verge of collapse. By comparison, both Zhao Ziyang and Gorbachev did have something in common, in that both the CCP and Chinese scholars would have had difficulty in claiming that their ideas on reform were in contravention of socialism. Firstly, according to their own words, neither of the communist leaders had ever thought of recommending the overthrow of the socialist systems operating in their respective countries. After being purged, Zhao revealed that what he had wanted was democracy under the CCP and rule of law in a socialist China [Bao 2009, 257]. In his official speeches Gorbachev always emphasised the fact that his goal was "socialist democracy", which involved "self-control" and "the unity of rights and duties" [Gorbachev 1987b, 169-170]. Secondly, at the 1987 13th Party Congress, Zhao expressed a firm resolve to shatter the "current political structure, which took shape during the revolutionary war years". According to him, the system was "no longer suited to our drive for modernisation in economic, political, cultural and other fields under conditions of peace, or to the development of a socialist commodity economy" [Zhao 1987, 59]. The revolutionary "political structure" Zhao was referring to was none other than the institution created by Mao after 1949, of which unpleasant vestiges remained even after 1976. As mentioned above, many Chinese scholars approved of Gorbachev's endeavours in re-assessing past errors and returning the Soviet state to the fundamental ethos of Leninism. These efforts of Gorbachev's corresponded to Zhao's proposal to transform the socialist state that had been created through war and revolution into a state designed to achieve construction and modernisation. This notion was given a consensus among the CCP leadership even after Zhao's purge, and was consistently implemented both in and after the 1990s [Deng 1994b, 314; Jiang vol. 1, 2006, 217]. In actuality, although in the eyes of Chinese communists writing after the 1990s both Zhao's political reform and Gorbachev's glasnost had some negative impacts, however, the CCP indictment of Zhao, as State Council spokesman Yuan $\mathrm{Mu}$ conveyed, was not because Zhao had suggested dissolving Party rule as part of his political reform, but because of the mistake Zhao made in "supporting the turmoil and splitting the Communist Party Central Committee". Zhao's removal was thus "only a measure of Party discipline" [Beijing Review $24^{\text {th }}-30^{\text {th }}$ July $1989,5]$. The statement points to the cause of Zhao's purge as being his refusal to endorse the CCP's decision to use force to put down the Tiananmen demonstrators, 
which in Deng Xiaoping's eyes was not only injurious to state interests but also a betrayal of socialist principles.

Zhao's biggest problem, manifested in his disagreement with the method of suppressing the Tiananmen protests, was his tolerance of dissent and his respect for human rights, which were similar to Gorbachev's "humanistic socialism", a characteristic that had been attacked by some Chinese scholars after 1991 as being too soft and compromising an attitude towards the anti-communist upheavals in Eastern Europe and the Soviet Union [Lu 1992, 51-56; Zhang 1993, 66-67; Chen 1994, 40]. Zhao's liberal attitude towards dissent was well known even before the Tiananmen Incident. He once remarked that the campaign against bourgeois liberalisation should not be too excessive, and that the people who had committed mistakes in the eyes of the Party should be allowed to "keep their posts and give full play to their professional knowledge" [Zhao 1987]. Similarly, one of the aspects for which Gorbachev had been heavily criticised by Chinese scholars was his negligence of the Marxist elements of class struggle and his sympathy for the enemies of socialism. Many scholars explicitly questioned why the Soviet leader did not send troops into Eastern Europe when the communist powers there were being overthrown, and crush the domestic anti-socialist force when the Soviet state was under threat [Zhou 1991, 17-20; Tong 1993, 12; Ma 1997, 12-13; Wu 1999, 5].

Therefore, to some extent, the all-out post-1990 Chinese criticism of Gorbachev had more to do with the Soviet leader's renunciation of the use of force in suppressing the anti-socialist movement than with his political reforms. These criticisms could be considered as a surreptitious way of justifying the CCP's brutal suppression of the Tiananmen demonstrations which was seen as an effective and prompt method of defeating the anti-party force. Judging from the publication dates of the writings, in the wake of Tiananmen, Chinese scholars had few criticisms to make of Gorbachev. However, after the Soviet economy deteriorated and domestic turbulence began to unfold in 1990, coinciding with Gorbachev's announcement of his decision to terminate the power monopoly of the CPSU, many Chinese scholars stopped praising Gorbachev, and after the collapse of the Soviet Union in 1991 their criticisms intensified. The contrasting pictures of post-1989 China and the post-1990 USSR (or Russia after 1991) led some to conclude that Gorbachev's failure was not caused by socialism, but was because he had not made a firm commitment to socialism. They argued that the chaotic situation in many post-socialist states demonstrated the disastrous outcomes of renouncing socialism for a country [Shao 1990, 2; Li 1992, 42; Cai 1995, 65], while the fact that China had survived demonstrated the positive outcomes of taking a firm stance to support the continuation of socialism in the country. Their criticisms of Gorbachev in hindsight might have given the public the impression that soft approaches and lax ideologies brought about nothing but tensions and mayhem in a socialist country, whereas tough measures ensured order and stability. Through their attacks on Gorbachev's relaxed attitude, the criticisms served to justify not only the CCP's violent crackdown on the Tiananmen protesters, but also Deng's post-Tiananmen announcement of his intention to maintain stability in China (which was synonymous with retaining the monopoly of CCP power) at any cost [Deng 1994b, 315].

\section{Conclusion}

The existing secondary literature seems to have exaggerated the impact of Gorbachev on 1980s China. Previous scholarship suggests that after the mid-1980s 
Chinese Soviet-watchers identified Gorbachev's concept of glasnost and his political reforms with Western democracy, and used Gorbachev and his ideas to push the Chinese regime towards political democratisation on the eve of the Tiananmen Incident. This paper, however, has shown that 1980s Chinese scholars interpreted glasnost in a way designed to serve their own purposes, and that this interpretation was quite different from democracy in the Western sense. The Chinese definition of glasnost remains entrapped in China's own mentality and history, reflecting the Chinese traditional understanding of human values and political culture. Moreover, few Chinese scholars used Gorbachev and his programmes to pressure the CCP to introduce some form of political Westernisation. Instead, most scholars manipulated the symbol of Gorbachev to support the reformist wing led by Zhao Ziyang in their factional warfare against the Party conservatives leading up to Tiananmen. In short, Chinese scholars did not regard Gorbachev and his programmes as having the potential to transform the political landscape of the PRC; rather, they perceived Gorbachev and his agenda as a tool that could be used to define, achieve and legitimise a reformed communist system on their own terms. The attractiveness of Gorbachev's glasnost to Chinese intellectuals in the 1980s claimed by the secondary literature is thus more of a myth than a reality.

Moreover, in contrast to the secondary literature, which suggests that Chinese criticisms of Gorbachev after Tiananmen were to do with his role in embracing democratisation and its disruptive repercussions in China, this paper has shown that the negative attitude of Chinese intellectuals towards the last Soviet leader after 1989 was more the result of Gorbachev's inability to use tough measures to prevent socialism in Europe from collapsing than anything else. Their criticisms of Gorbachev served to justify the Chinese government's brutal crackdown on civilian protests and to glorify the Party's role as a vanguard of state unity and stability. Many Chinese scholars were seemingly mounting efforts in defence of Deng's iron-fist policies, which had successfully preserved the socialist rule and ushered China down the road of prosperity since the 1990s, comparing this with the faltering Soviet state that would eventually lurch into disorder and break down under Gorbachev's liberalisation and hands-off approach, and leading people to conclude that a strong authoritarian rule that ensured political stability was far preferable.

Having said this, in and after the mid-1990s, as a strategic partnership was formed between the PRC and Russia after the end of the Cold War, and with the increasing amount of bilateral economic and security cooperation, Chinese scholars reduced their criticisms of Gorbachev. Moreover, Chinese Soviet-watchers took account of the bitter lessons learned from the Sino-Soviet hostilities that had taken place under Mao Zedong, in which name-calling and exchanges of verbal attacks had severely damaged relations between the two countries. They made it clear that this tragedy should not be repeated, and this understanding also restrained them from excessively criticising the last Soviet leader.

\section{REFERENCES}

Bao, Pu (2009), Prisoner of the State: The Secret Journal of Zhao Ziyang, Simon \& Schuster, London.

Baum R. (2008), “Zhao Ziyang and China's 'Soft Authoritarian' Alternative”, in Wu Guoguang and Helen Lansdowne (eds.), Zhao Ziyang and China's Political Future, Routledge, London, pp. 109-121. 


\section{p. 5 .}

Beijing Review (1986), “Democracy Essential to Policy Making”, August 11,

Beijing Review (1989), "Martial Law Kept in Force", July 24-30, p. 5.

Beijing Review (1989), "Premier Li on Internal, External Policies", April 1723, p. 12 .

Beijing Review (1989), "Qian Qichen on China's Foreign Policy”, April 10 16, p. 14.

Bernstein T. (2010), "Introduction: The Complexities of Learning from the Soviet Union", in Thomas Bernstein and Hua-yu Li (eds.), China Learns from the Soviet Union, 1949-Present, Lexington Books, Lanham, pp. 1-26.

Brown A. (2007), Seven Years that Changed the World: Perestroika in Perspective, Oxford University Press, Oxford.

Cai Song 蔡松 (1995), "Ershi yishiji jiangshi shehui zhuyi fuxinde shiji" 21 世纪将是社会主义复兴的世纪 (The $21^{\text {st }}$ Century Will Be the Century of Socialist Revival), Shehui zhuyi yanjiu 社会主义研究 (Socialism Studies), No. 6, pp. 62-65.

Cai Yimin 蔡毅民 (1986), “Jianshe gaodu minzhuyu duiwai kaifang”建设高度 民主与对外开放 (Building Good Democracy and Open-door Policy), Shehui zhuyi yanjiu (Socialism Studies), No. 4, pp. 23-24.

Chen Kairen 陈开仁 (1994), "Ouzhou gongchan zhuyi quanmian shuailuode yuanyin fouxi” 欧洲共产主义全面衰落的原因剖析 (Analysis on the Complete Fall of European Communism), Shehui zhuyi yanjiu (Socialism Studies), No. 3, pp. 37-40.

Cui Shumei 崔淑梅 (1988), “Gongkaixing yuanzeshi shehui zhuyi minzhude jiben tezheng” 公开性原则是社会主义民主的基本特征 (The Principle of Glasnost is the Fundamental Characteristic of Socialist Democracy), Kexue shehui zhuyi 科 学社会主义 (Scientific Socialism), No. 4, pp. 42-46.

Deng Xiaoping (1994a), Selected Works of Deng Xiaoping, the Bureau for the Compilation and Translation of Works of Marx, Engels, Lenin and Stalin under the Central Committee of the Communist Party of China (trans.), Vol. 2, Foreign Languages Press, Beijing.

Deng Xiaoping (1994b), Selected Works of Deng Xiaoping, the Bureau for the Compilation and Translation of Works of Marx, Engels, Lenin and Stalin under the Central Committee of the Communist Party of China (trans.), Vol. 3, Foreign Languages Press, Beijing.

Dittmer L. (1994), China under Reform, Westview, Oxford.

Gao Fang 高放 (1988), “Tansulian zhengzhi tizhi gaige”谈苏联政治体制改革 (Talking on Soviet Political Structural Reform), Sulian dongou wenti 苏联东欧 问题 (Matters of the Soviet Union and Eastern Europe), No. 5, pp. 1-11.

Gao Fang 高放 (1988), “Wodang shisandade sanda gongxian” 我党十三大的三 大贡献 (Our Party's Three Great Contributions to the 13th Congress), Dangdai shijie shehui zhuyi wenti 当代世界社会主义问题 (Questions of the Contemporary World Socialism), No. 1, pp. 1-16.

Gu Guanfu and Chun-tu Hsueh (1990) "Sino-Soviet Ties Grow Steadily", Beijing Review, September 3-9, p. 11.

Gu Xuewu 亮学武 (1988), "Lungeerbaqiaofude shehui minzhuhua shexiang" 论戈尔巴乔夫的社会民主化设想 (On Gorbachev's Vision of Socialist Democratisation), Shijie jingjiyu zhengzhi 世界经济与政治 (World Economics and Politics), No. 5, pp. 24-29. 
Guan Guihai (2010), "The Influence of the Collapse of the Soviet Union on China's Political Choices", in Thomas Bernstein and Hua-yu Li (eds.), China Learns from the Soviet Union, 1949-Present, Lexington Books, Lanham, pp. 505516.

Guangming Ribao 光明日报 (Guangming Daily) (1989), “'Heping yanbian” shishehui zhuyide zhuyao weixian” “和平演变” 是社会主义的主要危险 (“Peaceful Evolution" is the Principle Threat to Socialism), September 4, p. 3.

Guangming Ribao 光明日报 (Guangming Daily) (1989), "Shehui zhuyi guojia gaige jingchengshi shenkede” 社会主义国家改革进程是深刻的 (The Reform Processes in the Socialist States Are Profound), May 18, p. 3.

Guangming Ribao 光明日报 (Guangming Daily) (1989), “Zhongsu lianhe gongbao" 中苏联合公报 (The Sino-Soviet Joint Declaration), May 19, p. 1.

Goldman M. (1994), Sowing the Seeds of Democracy in China: Political Reform in the Deng Xiaoping Era, Harvard University Press, Cambridge, MA.

Gooding J. (2001), Socialism in Russia: Lenin and His Legacy, 1890-1991, Palgrave, Basingstoke.

Gorbachev M. (1987a), Speeches and Writings, Vol. 1, Pergamon Press, Oxford.

Gorbachev M. (1987b), Speeches and Writings, Vol. 2, Pergamon Press, Oxford.

Gorbachev M. and Ikeda Daisaku (2005), translated by Gage, R., Moral Lessons of the Twentieth Century: Gorbachev and Ikeda on Buddhism and Communism, I. B. Tauris, London.

Hu Sheng 胡绳 (1988), “Shehui kexue mianlinde xingshihe renwu” 社会科学 面临的形势和任务 (The Situation and Tasks Facing the Social Sciences), Zhongguo shehui kexue 中国社会科学 (Social Sciences in China), No. 4, pp. 3-14.

Huang Zongliang 黄宗良 (1993), “Jianlun sulian jubiande yuanyinhe jiaoxun zhongde liuda guanxi” 简论苏联剧变的原因和教训中的六大关系 (Briefing on the Six Relationships regarding Reasons and Lessons of Soviet Disintegration), Eluosi zhongya dongou yanjiu 俄罗斯中亚东欧研究 (Studies of Russia, Central Asia, and Eastern Europe), No. 1, pp. 39-46.

Jiang Changbin 姜长斌 (1993), "Sugongzai dangde zhongda zuzhi yuanzehe shijian fangmiande shibai jiaoxun" 苏共在党的重大组织原则和实践方面的失 败教训 (Lessons of the Failure on the Party Organization of the CPSU), Eluosi zhongya dongou yanjiu (Studies of Russia, Central Asia, and Eastern Europe), No. 1, pp. 47-53.

Jiang Zemin 江泽民 (2006), Jiangzemin wenxuan 江泽民文选 (Selected Works of Jiang Zemin), Vol. 1, Remin chubanshe, Beijing.

Jie Fu (1985), "Gorbachev at the Helm", Beijing Review, May 6, p. 13.

Kagan R. (2008), The Return of History and the End of Dreams, Atlantic Books, London.

Laqueur W. (1989), The Long Road to Freedom: Russia and Glasnost, Douglas \& Mclntyre, Vancouver.

Lewin M. (1991), The Gorbachev Phenomenon: A Historical Interpretation, University of California Press, Berkeley.

Li Dezong 李德忠 (1992), “Jiushi niandai zhongguo mianlinde lishi jiyu” 90 年代中国面临的历史机遇 (The 1990s Historical Opportunities That China Faces), Shehui zhuyi yanjiu (Socialism Studies), No. 5, pp. 42-43. 
Li Jingjie 李静杰 (1999), “Fazhan mianxiang ershiyi shijide zhanlue xiezuo huoban guanxi” 发展面向21世纪的战略协作伙伴关系 (To Develop the Strategic and Cooperative Partner Relations in the 21st Century), Eluosi zhongya dongou yanjiu (Studies of Russia, Central Asia, and Eastern Europe), No. 5, p. 4.

Li Liangrong 李良荣 (1988), “Sugong dishi jiuci daibiao huiyi fenxi” 苏共第十 九次代表会议分析 (Analysis of the 19th CPSU Congress), Fudan xuebao 复旦学 报 (Fudan Journal), No. 5, pp. 94-97.

Ling Yunong 凌毓农 (1986), “Lunshehui zhuyi minzhu fazhanyu jingji tizhi gaigede tongbu guanxi” 论社会主义民主发展与经济体制改革的同步关系 (The Synchronic Relationship between the Development of Socialist Democracy and Economic Restructuring), Zhongguo shehui kexue (Social Sciences in China), No. 5, pp. 3-18.

Lu Houming 卢厚明 (1992), “"Rendaode minzhude shehui zhuyi” pingxi” “人道 的，民主的社会主义”评析 (Analysis of “Humanistic and Democratic Socialism”), Shijie jingjiyu zhengzhi (World Economics and Politics), No. 1, pp. 51-56.

Lukin A. (1991), "The Initial Soviet Reaction to the Events in China in 1989 and the Prospects for Sino-Soviet Relations", The China Quarterly, No. 125 (1), pp. 119-136.

Ma Baohua 马宝华 (1986), “Tangeerbaqiaofu zhizheng yilai sulian duihua zhengce dongxiang” 谈戈尔巴乔夫执政以来苏联对华政策动向 (On Gorbachev's China Policy since He Took Power), Sulian wenti yanjiu ziliao 苏联问题研究资料 (Research Materials on the Soviet Union), No. 1, pp. 51-54.

Ma Yan 马岩 (1997), “Yishi xingtaiyu sulian jieti” 意识形态与苏联解体 (Ideologies and the Soviet Disintegration), Makesi zhuyi yanjiu 马克思主义研究 (Studies on Marxism), No. 3, pp. 2-13.

Marsh C. (2005), Unparalleled Reforms: China's Rise, Russia's Fall, and the Interdependence of Transition, Lexington Books, Oxford.

Pan Zhengxiang 潘正祥 (1999), “Zhongsucong jiemengdao duikangde jingyan jiaoxun” 中苏从结盟到对抗的经验教训 (The Lessons of Sino-Soviet Relations from Alliance to Confrontation), Dangdai shijie shehui zhuyi wenti (Questions of the Contemporary World Socialism), No. 4, pp. 44-47.

Qin Xiaoying 秦晓鹰 (1989) “Zhongguo sanci guanyu quanwei zhuyide lunzhan” 中国三次关于权威主义的论战 (Three Debates on Authoritarianism in China), Jingjixue zhoubao 经济学周报 (Economics Weekly), March 12, pp. 22-24.

Renmin Ribao 人民日报 (People's Daily) (1988), “Boyibo zhichu, gaige xuyao chuangxin jingshen” 薄一波指出, 改革需要创新精神 (Bo Yibo Points Out, Reform Needs the Spirit of Being Innovative), July 13, p. 1.

Renmin Ribao 人民日报 (People's Daily) (1992), “Eluosi zongtong yeliqin huijian qianqichen” 俄罗斯总统叶利钦会见钱其琛 (Russian President Yeltsin Meets Qian Qichen), November 26, p. 1.

Renmin Ribao 人民日报 (People's Daily) (1990), “Lipengzai mosike juxing jizhe zhaodaihui” 李鹏在莫斯科举行记者招待会 (Li Peng Holds Press Conference in Moscow), April 27, p. 4.

Renmin Ribao 人民日报 (People's Daily) (1990), “Qiaoshi huijian sugong zhongyang daibiaotuan” 乔石会见苏共中央代表团 (Qiao Shi Meets the CPSU Delegation), May 31, p. 3.

Renmin Ribao 人民日报 (People's Daily) (1989), “Shekeyuan tuichu gaige siluhe mubiao" 社科院推出改革思路和目标 (CASS Introduces the Plan and Goal of Reform), January 17, p. 3. 
Renmin Ribao 人民日报 (People's Daily) (1988), “Tianjiyunshuo, zhongsu kezai gaige juti zuofashang huxiang jiejian” 田纪云说, 中苏可在改革具体做法上 互相借鉴 (Tian Jiyun Says, China and the USSR Can Exchange the Reform Experiences with Each Other), January 11, p. 4.

Renmin Ribao 人民日报 (People's Daily) (1986), “Woguo zhubu gaige zhengzhi tizhi shiying jingji fazhan” 我国逐步改革政治体制适应经济发展 (Our Country Shall Reform the Political System Gradually for Adjusting to Economic Development), August 6, p. 1.

Renmin Ribao 人民日报 (People's Daily) (1994), “Zhonge lianhe shengming” 中俄联合公报 (The Sino-Russian Joint Declaration), September 4, p. 1.

Renmin Ribao 人民日报 (People's Daily) (1988), “Zhonggong zhongyang chengli zhengzhi tizhi gaige yanjiushi” 中共中央成立政治体制改革研究所 (The Political Structural Reform Research Office is Founded by the Central Committee of the CCP), February 28, p. 1.

Renmin Ribao 人民日报 (People's Daily) (1987), “Zhonggong zhongyang zhengzhiju kuoda huiyi gongbao" 中共中央政治局扩大会议公报 (Report of the Enlarged Meeting of the CCP Central Committee), January 17, p. 1.

Renmin Ribao 人民日报 (People's Daily) (1986), “Zhongsu zhengzhi guanxiwu shizhixing jinzhan” 中苏政治关系无实质性进展 (There Has Been no Concrete Progress for Sino-Soviet Political Relations), June 20, p. 1.

Rozman G. (2010), "China's Concurrent Debate about the Gorbachev Era", in Thomas Bernstein and Hua-yu Li (eds.), China Learns from the Soviet Union, 1949-Present, Lexington Books, Lanham, pp. 449-476.

Rozman G. (1987), The Chinese Debate about Soviet Socialism, 1978-1985, Princeton University Press, Princeton.

Sallnow J. (1989), Reform in the Soviet Union: Glasnost and the Future, Pinter, London.

Shambaugh D. (2008), China's Communist Party: Atrophy and Adaptation, University of California Press, Berkeley.

Shao Huaze 邵华泽 (1990), “Shenru xuexihe yanjiu shehui zhuyi lilun” 深入学 习和研究社会主义理论 (To Study and Research Thoughtfully on Socialist Theories), Shehui zhuyi yanjiu (Socialism Studies), No. 6, pp. 1-6.

Shen Yiming 沈一鸣 (1989), “Zhengzhi duoyuanhua” 政治多元化 (Political Pluralization), Dangdai shijie shehui zhuyi wenti (Questions of the Contemporary World Socialism), No. 2, pp. 21-22.

Shi Shudong 施舒冬 (1987), “Gaige, minzhu, ganbu” 改革, 民主, 干部 (Reforms, Democracy, Cadres), Dangdai shijie shehui zhuyi wenti (Questions of the Contemporary World Socialism), No. 1, pp. 1-7.

Su Shaozhi 苏绍智 (1988) “Gaigede liangda lishixing renwu” 改革的两大历史 性任务 (Two Significant Historical Tasks of Reforms), Renmin ribao (People's Daily), March 5, p. 5.

The Editorial Board 编辑部 (1986), “Duiwenge delishi fansi” 对文革的历史反 思 (The Historical Re-examination of the Cultural Revolution), Shehui kexue yan$j i u$ 社会科学研究 (Social Sciences Research), No. 5, pp. 126-129.

Tong Baochang 佟宝昌 (1993), “Sulian jubiande jiaoxun” 苏联剧变的教训 (Lessons of the Soviet Turbulence), Eluosi zhongya dongou yanjiu (Studies of Russia, Central Asia, and Eastern Europe), No. 3, pp. 8-13.

Walker R. (1993), Six Years that Shook the World: Perestroika - the Impossible Project, Manchester University Press, Manchester. 
Wang Yizhou 王逸舟 (1989), “Sulianhe zhongguo" 苏联和中国 (The Soviet Union and China), Zhongguo shehui kexueyuan yanjiushengyuan xuebao 中国社 会科学院研究生院学报 (Journal of Graduate School of Chinese Academy of Social Sciences), No. 3, pp. 20-25.

Wei Cizu 韦慈竹 (1991), “Minzhu shehui zhuyi pouxi” 民主社会主义剖析 (Analysis of Democratic Socialism), Dangdai shijie shehui zhuyi wenti (Questions of the Contemporary World Socialism), No. 4, pp. 16-19.

Wilson J. (2007), "The Impact of the Demise of State Socialism on China", in David Lane (ed), The Transformation of State Socialism: System Change, Capitalism or Something Else?, Palgrave Macmillan, New York, pp. 269-285.

Wu Guoguang (2008), "Democracy and Rule of Law in Zhao Ziyang's Political Reform", in Wu Guoguang and Helen Lansdowne (eds.), Zhao Ziyang and China's Political Future, Routledge, London, pp. 32-57.

Wu Guoguang 吴国光 (1997), Zhaoziyang yuzhengzhi gaige 赵紫阳与政治 改革 (Political Reform under Zhao Ziyang), The Pacific Century Institute, Hong Kong.

Wu Qingan 武庆安 (1988), “Jianlun woguo shehui zhuyi chuji jieduande teshuxing jiqi renwu” 简论我国社会主义初级阶段的特殊性及其任务 (A Brief Discussion of the Special Task in the Primary Stage of Socialism in China), Shehui kexue jikan 社会科学辑刊 (Social Science Journal), No. 6, pp. 25-26.

Wu Raohui 吴耀辉 (1987), “Sulian dongou guojia zhengzhi tizhi gaigede lishi kaocha” 苏联东欧国家政治体制改革的历史考察 (A Historical Survey of the Political System Restructuring in the USSR and the East European Countries), Shehui kexue 社会科学 (Social Sciences), No. 8, pp. 11-16.

Wu Wei 吴伟 (1999), “Kelimulingong dehongxing shizenyang yunluode” 克里 姆林宫的红星是怎样陨落的 (How the Red Star on the Kremlin Fell), Eluosi yanjiu 俄罗斯研究 (Russian Studies), No. 1, pp. 1-18.

Xenakis C. (2002), What Happened to the Soviet Union?: How and Why American Sovietologists were Caught by Surprise, Praeger, London.

Xiao Gu 晓古 (1988), “Sulian zhengzhi tizhi gaige chutan”苏联政治体制改革 初探 (Initial Inquiries on Soviet Political Structural Reform), Guoji guancha 国际 观察 (International Review), No. 2, pp. 6-11.

Xing Shugang 邢书纲 (1986), “Guanyu geerbaqiaofu deyuandong zhixing" 关于戈尔巴乔夫的远东之行 (On Gorbachev's Trip to the Far East), Sulian dongou wenti (Matters of the Soviet Union and Eastern Europe), No. 6, pp. 34-37.

Xu Dashen 徐达深 (1989), "Xinxingshi xiade meiguo heping yanbian zhanlue" 新形势下的美国和平演变战略 (American Strategy of Peaceful Evolution under the New Situation), Shijie jingjiyu zhengzhi (World Economics and Politics), No. 11, pp. 3-7.

Xu Hongwu 徐鸿武 (1988), “Kaituo shehui zhuyi minzhu zhengzhi jianshede xinshiye" 开拓社会主义民主政治建设的新视野 (To Open Up the New Horizon of the Construction of Socialist Democratic Politics), Shehui zhuyi yanjiu (Socialism Studies), No. 3, pp. 21-24.

Xu Zhixin 许志新 (1991), “Julie dongdangde sulian jushi” 剧烈动荡的苏联 局势 (The Turbulent Soviet State), Sulian dongou wenti (Matters of the Soviet Union and Eastern Europe), No. 3, pp. 9-21.

Yan Shuhan 严书翰 (1990), “Shehui zhuyi lilun”社会主义理论 (Socialist Theories), Shehui zhuyi yanjiu (Socialism Studies), No. 4, pp. 1-5. 
Yan Xiu 严秀 (1988), “Yanlunyu xinshuai” 言论与兴衰 (Speech and Decay), Renmin Ribao (People's Daily), February 2, p. 8.

Yang Xinyu 杨心宇 (1988), "Duisugong dishi jiuci daibiao huiyi guanyu zhengzhi tizhi gaige fangande pingxi” 对苏共第十九次代表会议关于政治体制 改革方案的评析 (On the CPSU Nineteenth Conference and Its Political Reform Proposal), Sulian dongou wenti (Matters of the Soviet Union and Eastern Europe), No. 5, pp. 19-22.

Zhang Jindou 张金斗 (1992), “Qiantan sulian gaigede shiwu” 浅谈苏联改革的 失误 (On the Faults of Soviet Reforms), Sulian wenti yanjiu ziliao (Research Materials on the Soviet Union), No. 1, pp. 16-21.

Zhang Shigu 张式谷 (1991) "Baxuexi heyanjiu kexue shehui zhuyi tidao shouyao diwei” 把学习和研究科学社会主义提到首要地位 (Treating the Study and Research on Scientific Socialism as the First Importance), Guangming Ribao (Guangming Daily), August 26, p. 3.

Zhang Wei 张伟 (1989), “Sulian zhengzhi tizhi gaige jianxi” 苏联政治体制改 革简析 (Brief Survey on Soviet Political Structural Reform), Zhengzhixue yanjiu 政治学研究 (Journal of Political Science), No. 5, pp. 66-68.

Zhang Zesen 张泽森 (1993), “Geerbaqiaofu dexinsiwei jiqidui qiansulian deyingxiang” 戈尔巴乔夫的新思维及其对前苏联的影响 (Gorbachev's New Thinking and the Effects on the Former USSR), Dangdai shijie shehui zhuyi wenti (Questions of the Contemporary World Socialism), No. 3, pp. 65-67.

Zhao Liqing 赵黎青 (1989), “Lunminzhu quanwei zhuyi” 论民主权威主义 (On Democratic Authoritarianism), Shehui zhuyi yanjiu (Socialism Studies), No. 4, pp. 36-39.

Zhao Longgeng 赵龙庚 (1988), “Suliande zhengzhi moshide biange” 苏联政治 模式的变革 (Reform of the Soviet Political Model), Xiandai guoji guanxi 现代国 际关系 (Contemporary International Relations), No. 4, pp. 10-15.

Zhao Yuliang 赵玉梁 (1988), “Xinsiwei, gongkaixing, wenhua geming” 新思 维, 公开性, 文化革命 (New Thinking, Glasnost, Cultural Revolution), Shijie jingjiyu zhengzhi (World Economics and Politics), No. 10, pp. 22-27.

Zhao Ziyang (1987), "Advance Along the Road of Socialism with Chinese Characteristics", in Beijing Foreign Language Press (ed.), Documents of the Thirteenth National Congress of the Communist Party of China, Beijing Foreign Language Press, Beijing, pp. 3-77.

Zheng Jianxin 郑建新 (1988), “Geerbaqiaofu qirenyu suliande gaige” 戈尔巴 乔夫其人与苏联的改革 (Gorbachev and the Soviet Reforms), Sulian dongou wen$t i$ (Matters of the Soviet Union and Eastern Europe), No. 5, pp. 22-29.

Zheng Yifan 郑异凡 (1995), "Yiguo jiancheng shehui zhuyi lilun xinping”一国 建成社会主义理论新评 (A New Comment on the Theory of Socialism in One Country), Dangdai shijieyu shehui zhuyi 当代世界与社会主义 (Contemporary World and Socialism), No. 1, pp. 7-12.

Zhou Xincheng 周新城 (1991), “Liangtiao zhongyaode jiaoxun” 两条重要 的教训 (Two Important Lessons), Beijing shehui kexue 北京社会科学 (Social Sciences of Beijing), No. 4, pp. 13-20.

Zhou Yuansheng 周院生 (1988), “Sulian gongkaixing yuanze” 苏联公开性原 则 (The Principle of Soviet Glasnost), Sulian wenti yanjiu ziliao (Research Materials on the Soviet Union), No. 3, pp. 23-26.

Zhu Ruizhen 朱瑞真 (1987), "Pinggeerbaqiaofu guanyu jiejue yazhou anquan wentide shexiang” 评戈尔巴乔夫关于解决亚洲安全问题的设想 (On Gorbachev's 
Proposal for the Solution of Asian Security Problems), Sulian dongou wenti (Matters of the Soviet Union and Eastern Europe), No. 3, pp. 25-31.

Zong Fengming 宗凤鸣 (2007), Zhaoziyang ruanjin zhongde tanhua 赵紫阳软 禁中的谈话 (Zhao Ziyang: Captive Conversations), Open Books, Hong Kong.

Zuo Fengrong 左凤荣 (1996), “Yeping sidalin 'yiguo jiancheng shehui zhuyi” lilun”也评斯大林 “一国建成社会主义” 理论 (On Stalin's Theory of “Socialism in One Country"), Dangdai shijie shehui zhuyi wenti (Questions of the Contemporary World Socialism), No. 2, pp. 57-63.

\section{ДЕБАТИ ПРО СОЦІАЛІЗМ У КИТАЇ 1980-x-1990-х: НА ПРИКЛАДІ ГОРБАЧОВСЬКОЇ ГЛАСНОСТІ}

Цзє Лi

Гласність Михайла Горбачова була популярною темою у Китаї 1980-х. У наявних дослідженнях зазначається, що китайські спостерігачі за Радянським Союзом захоплювалися програмою Горбачова як моделлю для демократизації Китаю у 1980-х. Проте після 1991 р., через їхній вплив на про-демократичні рухи Китаю (як вважалося китайським урядом), ті самі вчені постійно критикували Горбачова і його політику лібералізації за те, що вона була основним каталізатором розпаду СРСР.

У пропонованій статті припускається, що привабливість політики гласності Горбачова для китайських дослідників Радянського Союзу пояснювалася не тим, що вона символізувала демократію західного типу; навпаки, вони сприймали гласність як тип демократії, керованої урядом. Вплив політики Горбачова після середини 1990-х також можна простежити у її використанні китайськими дослідниками, щоб підтримати реформістського генерального секретаря Чжао Цзияна в його боротьбі за владу проти партійних консерваторів, яка призвела до подій на площі Тяньаньмень.

У статті також йдеться, що неприязнь китайських дослідників до Горбачова після подій на площі Тяньаньмень передусім була зумовлена не його роллю у сприянні демократизації; швидше, вона виникла через м'який підхід Горбачова щодо інакомислення, коли комунізм у Європі був на межі краху. Привертаючи увагу до м'якого підходу Горбачова, китайські критики виправдовували використання Китаєм репресій на площі Тяньаньмень і жорстких заходів, прийнятих Ден Сяопінем, щоб зберегти соціалістичний лад і соціальну стабільність.

Ключові слова: Михайло Горбачов, Ден Сяопін, Чжао Цзиян, китайська Совєтологія, Тяньаньмень, сучасний Китай, посткомунізм

\section{ДЕБАТЫ ПРО СОЦИАЛИЗМ В КИТАЕ 1980-х-1990-х: НА ПРИМЕРЕ ГОРБАЧОВСКОЙ ГЛАСНОСТИ}

Цзе Ли

Гласность Михаила Горбачова была популярной темой в Китае 1980-х. В имеющихся исследованиях отмечается, что китайские наблюдатели за Советским Союзом восхищались программой Горбачева как моделью для демократизации Китая в 1980-х. Однако после 1991 г. из-за их влияния на про-демократические движения Китая (как считало китайское правительство), те же самые ученые постоянно критиковали Горбачева и его политику либерализации за то, что она стала основным катализатором распада СССР.

В данной статье предполагается, что привлекательность политики гласности Горбачева для китайских исследователей Советского Союза объяснялась не тем, что она символизировала демократию нового типа; напротив, они воспринимали гласность как тип демократии, управляемой правительством. Влияние политики Горбачева после середины 1990-х также можно увидеть в ее использовании китайскими 
исследователями, чтобы поддержать реформистского генерального секретаря Чжао Цзыяна в его борьбе за власть против партийных консерваторов, которая привела к событиям на площади Тяньаньмень.

В статье также отмечается, что неприязнь китайских исследователей к Горбачеву после инцидента Тяньаньмень прежде всего была обусловлена не его ролью в содействии демократизации; скорее, она возникла из-за мягкого подхода Горбачова к инакомыслию, когда коммунизм в Европе был на грани краха. Привлекая внимание к мягкому подходу Горбачева, китайские критики оправдывали использование Китаем репрессий на площади Тяньаньмень и жестких мер, принятых Дэн Сяопином для сохранения социалистического строя и социальной стабильности.

Ключевые слова: Михаил Горбачев, Дэн Сяопин, Чжао Цзыян, китайская Советология, Тяньаньмень, совремнный Китай, посткоммунизм

Стаття надійшла до редакиії 26.02.2020 